\title{
Richard FitzRalph of Dundalk (c. 1300-1360) and the New World
}

Author(s): Michael Dunne

Source: Archivium Hibernicum, Vol. 58 (2004), pp. 243-258

Published by: Catholic Historical Society of Ireland

Stable URL: https://www.jstor.org/stable/25529639

Accessed: 19-08-2019 13:53 UTC

JSTOR is a not-for-profit service that helps scholars, researchers, and students discover, use, and build upon a wide range of content in a trusted digital archive. We use information technology and tools to increase productivity and facilitate new forms of scholarship. For more information about JSTOR, please contact support@jstor.org.

Your use of the JSTOR archive indicates your acceptance of the Terms \& Conditions of Use, available at https://about.jstor.org/terms

Catholic Historical Society of Ireland is collaborating with JSTOR to digitize, preserve and extend access to Archivium Hibernicum 


\section{Richard FitzRalph of Dundalk (c.1300-1360) and the New World ${ }^{\mathrm{I}}$}

Richard FitzRalph was one of the most significant Irish authors of the medieval period. This article looks at his notion of dominium which concerned the problem of lordship or ownership over goods and people. Racial tensions within his own diocese of Armagh formed the context for his treatment of the theme. In particular he was concerned that some of his Anglo-Norman subjects justified the seizure of property belonging to their Gaelic neighbours by appealing to march law (lex marchie). FitzRalph sought a theory of property that would apply equally to all. In elaborating his system, which became influential in the West, the Irishman drew on a rich philosophical and theological tradition. While the term dominium had already been used by St Augustine, it was Peter Lombard who popularised it in the fourth book of the Sentences. This article examines FitzRalph's use of the term, his influence on John Wyclif and Francisco de Vitoria and the role of his thought in the sixteenth-century university disputes provoked by the 'discovery' of the New World.

Fitzralph was born Richard Rauf at Dundalk around 1300 into an AngloNorman family. Although his family were respectable they do not seem to have

I This article is based upon a paper presented to the Faculty of Philosophy, National University of Ireland, Maynoot,ash in March 2003. I wish to thank my colleague, Prof. James McEvoy, for having read the paper and for his suggestions. The standard work on the life and career of FitzRalph is Katherine Walsh, A fourteenth-century scholar and primate: Richard FitzRalph in Oxford, Avignon and Armagh (Oxford, 198I) and, by the same author, 'Archbishop Fitz-Ralph and the Friars at the Papal Court in Avignon, 1357-60' in Traditio 31 (1975) pp 223-45; 'Der Becket der Irisher Kirche: Der "Armachanus" Richard FitzRalph von Armagh ( $\dagger_{1360}$ ). Professor, Kirchenfürst, Heiliger' in Innsbrucker Historische Studien 20/2I (1999), pp I-58; her article on FitzRalph in NewDNB. A more recent examination of FitzRalph's Irish background and education at Oxford is to be found in Michael Dunne, 'A fourteenth-century example of an Introitus Sententiarum at Oxford: Richard FitzRalph's Inaugural Speech in praise of the Sentences of Peter Lombard' in Medieval Studies [Toronto], 63 (200I), pp I-29. A full list of surviving works, manuscripts and editions is to be found in R. Sharpe, A Handlist of Latin Writers of Great Britain and Ireland before 1540 (Turnhout, 1997) pp 478-8I. Still of relevance on FitzRalph's life and career are the following by A. Gwynn, S.J., 'The Black Death in Ireland' in Studies 24 (1935), pp 25-42; 'Archbishop FitzRalph and George of Hungary' in Studies 24 (1935), pp 558-72; 'Richard FitzRalph, Archbishop of Armagh in Studies 25 (1936), pp 8I96; 'Archbishop FitzRalph and the Friars' in Studies 26 (1937), pp 50-67; 'The Sermon Diary of Richard FitzRalph' in Proceedings of the Royal Irish Academy 44 (1937), section C, no. I, pp I-57; 'Two Sermons of Primate Richard Fitzralph preached before the Provincial Councils of Armagh on 7 February 1352 and 5 February I355' in Archivium Hibernicum XIV (1949) pp 50-65. Also useful are M. J. Haren, 'Richard FitzRalph and the Friars: the Intellectual Itinerary of a Curial Controversialist' in J. Hamesse (ed.), Roma, Magistra Mundi. Itineraria Culturae Medievalis. Mélanges offerts au P. L.E. Boyle (Louvain-la-Neuve, 1998), vol. I, pp 349-67; G. Leff, Richard FitzRalph, Commentator of the Sentences. A Study in Theological Orthodoxy (Manchester, 1963). 
been well off. It may have been desire to forget his lowly origins that led Richard to change his name, before 1325 , to FitzRalph, inspired, perhaps, by an imagined or wished-for connection with the English family of that name. The details of his early life are sparse. He tells us that some relatives were members of the Franciscan order in Dundalk. ${ }^{2}$ It may be supposed that he received his elementary education at Dundalk, and since the Franciscan friary was the only religious house in the town, it may have been there that he went to school.

The lack of a local university meant that students like FitzRalph had to travel abroad for higher education. ${ }^{3}$ There is evidence of Irish students, Gaelic as well as Norman, at Oxford, Paris and other centres. ${ }^{4}$ Oxford, however, remained the place of choice for most Irish student peripatetics. Firauf (as he is called by his contemporaries) came to Oxford as a secular student in arts, probably at the customary age of fifteen. He was a fellow of Balliol College by 1322 when he incepted as a master in arts, having completed the seven liberal arts and the three philosophies (natural, moral and metaphysics). 5 As a student in theology he seems to have gone to University Hall. FitzRalph was bachalarius in sacra pagina after August 1328 and he had completed his lectures on the Sentences before October $1329 .{ }^{6}$ At Paris from 1329-30, his inception as doctor seems to have taken place in the summer of 133 . He became chancellor of the University of Oxford in 1332.

In 1335 FitzRalph was appointed dean of Lichfield and remained at Lichfield until 1346 when he was appointed archbishop of Armagh, being consecrated at Exeter Cathedral in 1347 . He became one of the most outstanding bishops of his time, producing a number of influential works including the Summa de quaestionibus Armenorum, De pauperie Salvatoris (c.1350-6) (which would have such an influence on Wyclif) and Defensio Curatorum. He is best known to historians because of his anti-mendicant stance. After his death his tomb became a centre of pilgrimage. In the margin of a page from the manuscript of the Martyrologium Dungallense, now conserved at the National Library in Brussels, the scribe copied the following verse in Middle English: 'Manny a mile have I gone/and manny did I walk/But neuer sawe a hollier man/than Richard of Dundalk'. 7 There are a number of

\footnotetext{
2 See Walsh, A fourteenth-century scholar and primate, p. I. 3 On the various attempts to found an Irish university, see Walsh, pp II-I3. On the clerical traffic between Ireland and England at this time, see Virginia Davis 'Material relating to Irish clergy in England in the late Middle Ages' in Archivium Hibernicum LVI (2002), pp 7-50. 4 A century beforehand, Peter of Ireland had studied and travelled as far as Italy, where he held a chair at the University of Naples. His extant works have been edited. See M. Dunne (ed.) 'Magistri Petri de Ybernia, Expositio et Quaestiones in Aristotelis librum De longitudine et brevitate vitae' in Philosophes Médiévaux XXX (Louvain-Paris, 1993); M. Dunne (ed.) 'Magistri Petri de Ybernia, Expositio et Quaestiones in Peryermenias Aristotelis' in Philosophes Médiévaux XXXIV (Louvain-Paris, 1996). See also James McEvoy 'Maître Pierre d'Irlande, professeur in naturalibus à l'université de Naples' in J. Follon and J. McEvoy (eds), Actualité de la pensée médiévale (Louvain, 1994), pp I46-58. 5 See Walsh, A fourteenth-century scholar and primate, p. 5. 6 The present author is preparing a critical edition of FitzRalph's Lectura in Sententias Petri Lombardi for the Auctores Britannici Medii Aevi series of the British Academy. 7 Brussels, Bibl. Nat., MS 506, f.II5r. See Walsh, A fourteenth-century scholar and primate, p. 2, note.
} 
references to him in Middle English literature, particularly in moral tracts inspired by the Lollards. He is regarded as a saint by the Church of Ireland, which keeps his feast day on 7 June. There is a chapel dedicated to him in Dundalk's church of St Nicholas.

It was the situation in Ireland which first prompted FitzRalph to develop his own particular theory of dominion and law. FitzRalph ruled a culturally divided diocese. To the north was the ecclesia inter Hibernos, Gaelic-speaking and adhering to traditional law, land tenure and social customs. To the south was the ecclesia inter Anglos, dominated by Anglo-Norman settlers who observed the common law. ${ }^{8}$ His cathedral lay in the ecclesia inter Hibernos and had a Gaelic dean and chapter. However, he resided in the south at his two manors, Termonfechin and Dromiskin, and the parish church of St Peter at Drogheda acted as pro-cathedral. There was a history of tension between the two ecclesiae, especially in FitzRalph's youth, during the invasion of Edward Bruce in $1315-18$. Among the gravamina presented to Pope Clement V at the Council of Vienne, around I318, was a complaint that it was not regarded as a crime for an Englishman to deprive an Irishman of his property or even to take his life, something which FitzRalph would roundly condemn in his sermons some forty years later. ${ }^{9}$ However, FitzRalph would also accuse Franciscans of Gaelic origin within his diocese of abusing the confessional in order to excuse similar crimes committed against the English colonists. In a sermon given at the Carmelite church in Drogheda, on 25 March 1349, FitzRalph denounced the virtual civil war between the English and the Irish in the archdiocese and the climate of general theft and dishonesty. He pointed out to his hearers (who were all presumably Anglici, and had been recently stricken by Black Death) that the rival communities were under the impression that it was lawful not only to rob and plunder someone of the other community but even to kill them. ${ }^{10}$ FitzRalph reminded them that killing was justified only as selfdefence, and that, in cases of theft, full restitution was necessary. He condemned the manner in which racial tensions were used as a pretext for selfinterest and greed. Again, in a sermon given at Dundalk on 3 April 1356, he fulminated against those who destroyed his peace efforts and took the law into their own hands, on the grounds that they were acting according to the lex marchie of their forefathers. He had tried under a royal commission to make a

8 See J. A. Watt, The Church and the Two Nations In Medieval Ireland (Cambridge, 1970); 'Ecclesia inter Anglos et inter Hibernos: confrontation and coexistence in the medieval diocese of Armagh' in The English in Medieval Ireland, Proceedings of the first joint meeting of the Royal Irish Academy and the British Academy, ed. J. Lydon (Dublin 1984), pp 46-64; 'The Church and the Two Nations in Late Medieval Armagh' in The Churches, Ireland and the Irish, Studies in Church History 25, eds W. J. Shiels and D. Wood (Oxford, 1987), pp 37-54. See also K. Walsh, 'One Church and Two Nations: a uniquely Irish Phenomenon?' in Faith and Identity: Christian Political Experience, Studies in Church History, Subsidia 9, eds D. Loades and K. Walsh (Oxford, 1990), pp 8I-9I. K. Simms, 'Frontiers in the Irish Church - regional and cultural' in T. Barry, R. Frame and K. Simms (eds) Colony and Frontier in Medieval Ireland - Essays presented to James F. Lydon (London and Rio Grande, 1995), pp 176-200. 9 See Walsh, A fourteenth-century scholar and primate, pp 9-10. 1o See Walsh, $A$ fourteenthcentury scholar and primate, pp 325, 342. 
truce in August of 1348 , and some six years later he tried again to make peace with the O'Neill. He commented that while he could make peace with the leaders, their supporters would not agree and would not observe the truce. ${ }^{\text {II }}$

For Fitzralph, the seizure of land, on a legal pretext which might be valid per iudicium legis terrenae, was still a violence of the law of conscience and the law of God. This led him to raise an argument which he would later develop in the De Pauperie Salvatoris, namely that while the civil courts judged on the apparent visible realities and, due to limited information, could make a false judgment, nevertheless, falsum iudicium numqum transfert vere dominium. But how far was such a doctrine practicable in the circumstances of the time? His fulminations were directed primarily at his own Anglo-Norman kinfolk whom he blamed more than his Gaelic subjects. Like most of his educated medieval contemporaries, Fitzralph had high ideals regarding the Christian commonwealth, but he was a realist. St Thomas, for example, accepted that it was not the task of the state to make laws to compel people to be virtuous and that certain imperfection had to be tolerated for the sake of the greater good, freedom. ${ }^{12}$ FitzRalph agreed. In a sermon preached at Drogheda, on 2 December 1352, he again applied his theory of dominion and law but accepted that, for social reasons and the common good, hidden wrongs might have to be tolerated. ${ }^{13}$ This is a clear indication that while his theory of dominion laid claim to eternal validity it could not always be enforced under positive law.

FitzRalph reveals that he underwent a conversion to the truth of scripture that led him to dislike Aristotelianism. ${ }^{\mathrm{I}}$ The latter he shared with Nicholas of Autrecourt, who on 20 May 1346 was censured for his views. ${ }^{15}$ Nicholas had

II See Walsh, A fourteenth-century scholar and primate, pp 340-I. 12 See, for example, Summa theologiae (henceforth S. Th), II II, q. 78, a. I, co.: Human laws leave some sins unpunished because of the imperfection of men who would lack many things that are useful to them if all sins were strictly prohibited by the application of legal penalties. Therefore human law allows usury not because it considers it to be just but to avoid interference with the useful activities of many people. 13 See Walsh, A fourteenth-century scholar and primate, p. 325. 14 See the autobiographical prayer edited by L. L. Hammerich, The Beginnings of the Strife between Richard FitzRalph and the Mendicants (Copenhagen, 1938) p. 20. It seems that FitzRalph underwent a 'conversion' during the six years that he spent at the papal court (c. 1337-43). The text as translated in W. A. Pantin, The English Church in the Fourteenth Century (Cambridge, 1955), pp 132 -3, reads as follows: 'Nor were You, the Solid Truth, absent from me in those six years, but, in Your Holy Scriptures you shone upon me as in a certain radiant mirror; whereas in my former years, in the trifles of the philosophers, you had been hidden from me as in a certain dark cloud. For previously, I used to think that through the teachings of Aristotle and certain argumentations that were profound only to men profound in vanity, I used to think that I had penetrated to the depths of Your Truth, with the citizens of Your Heaven; until You, the Solid Truth, shone upon me in Your Scriptures, scattering the cloud of my error, and showing me how I was croaking in the marshes with the toads and frogs. For until I had You the Truth to lead me, I had heard, but did not understand, the tumult of the philosophers chattering against You, the pertinacious Jews, the proud Greeks, the carnal Saracens, and the unlearned Armenians... At last, O Solid Truth, You so shone on me from above, that I burned to seize and to hold You, the Truth, Jesus promised to us in the Law and Prophets. And when in the turmoil of lawsuits a certain spell of serenity had smiled upon me, I sought You in Your sacred Scriptures, intimately and importunately, not only by reading, but also with prayer, until You came to meet me joyously in Your ways'. 15 Nicholas of Autrecourt (c.1295-1369) was summoned by Pope Benedict XII to Avignon from Paris on 21 November 1340 to respond to allegations that he was teaching erroneous doctrines. He was convicted in 1346 by the papal commissions of Pope Clement VI and Cardinal Curti and four lists 
argued for common sense and for attention to realities rather than to the arguments of Aristotle and Averroës. For his part FitzRalph spent the latter years of his life defending a thesis of lordship and jurisdiction based on a perhaps questionable interpretation of Augustinian doctrine, and one that was radically opposed to the principles of Aristotelianism.

With the publication of his dialogue, the De pauperie Salvatoris of 1356 , FitzRalph made known to a wider audience his teaching on dominion or lordship based on grace. This work was to have far-reaching consequences in the later writings of Wyclif and Hus. Indeed, Wyclif's contemporaries were well aware that his source was FitzRalph, although Wyclif himself developed the implications of the Irishman's teaching in a way that the latter would not have condoned and seems not to have envisaged.

FitzRalph rarely mentions any authority for his view and cited only those who opposed it. There is no allusion to dominium in the commentary on the Sentences. Indeed we have to wait until the Summa de quaestionibus Armenorum (1340-4I, Book X, ch. 4), where he writes:

So far as I can judge no man in a state of mortal sin has true lordship over other creatures in God's sight. He ought rather to be called a tyrant, a thief or a robber, though he may keep the name of prince or lord, by reason of possession or hereditary succession, or the approval of the people who are subject to him, or by some other human law. But he has no true lordship until he repents, and until the grace of penance has restored him to a state that is acceptable to God. ${ }^{16}$

The late Aubrey Gwynn S.J. traced this doctrine back to some members of the Augustinian school, particularly to Giles of Rome, who put forward an extreme interpretation of De civitate Dei in 1302 at the height of the dispute between Boniface VIII and Philip the Fair in his De ecclesiastica potestate..$^{17}$ The

containing a total of sixty-six erroneous propositions were drawn up. Autrecourt formally recanted before 19 May 1346 and in November 1347, at a meeting of the masters of the University of Paris at the Church of St Mathurin, he publicly burned the lists of propositions and his treatise Exigit ordo (or the Tractatus Universalis). Autrecourt's principal error lay in his having rejected the concepts of substance and cause, which lay at the foundations of medieval metaphysics and epistemology. He concluded that we have no certainty regarding the material world and all that was left was a knowledge of the self. His form of scepticism is seen as anticipating similar doubts raised by David Hume in the eighteenth century. On the life and thought of Autrecourt, see M. Beuchot, 'Nicholas of Autrecourt' in $A$ Companion to Philosophy in the Middle Ages (Oxford, 2003), pp 458-65. It provides an up-to-date bibliography. 16 Quoted in A. Gwynn, The English Austin Friars in the Time of Wyclif (London, 1940), pP 59-73, especially p. 67. Gwynn's source is Johannes Sudoris's edition of the Summa de Erroribus Armenorum (Paris, 1514), p. 75v. 17 See A. Gwynn, The English Austin Friars in the Time of Wyclif, pp 60-6r. See also Aegidius Romanus, De ecclesiastica potestate (ed. R. Scholz, Weimar 1929). There is an English translation in R. W. Dyson, Giles of Rome on Ecclesiastical Power. The De ecclesiastica potestate of Aegidius Romanus (Woodbridge, 1986). See also C. Luna 'Un nuovo documento del conflitto tra Bonifacio VII e Filippo il Bello: il discorso "De potentia domini pape" di Egidio Romano' in Documenti e studi sulla tradizione filosofica medievale, 3 (1992), pp 167-243, 49I-559. For a recent assessment, see J. Miethke, De potestate papae. Die päpstliche Amtskompetenz im Widerstreit der politischen Theorie von Thomas von Aquin bis Wilhelm von Ockham (Tübingen, 200o) (Spätmittelalter und Reformation, Neue Reihe 16), pp 94-101. 
irony is that a theory which was developed to defend the hierocratic claims of the papacy would be used within the space of three generations to attack papal jurisdiction, as we shall see below.

Giles had argued that all lordship existed with justice only under and through the Church. From him only the faithful members of the Church enjoyed just and righteous lordship. Thus, justice was lacking in all those who, either through sin or lack of baptismal regeneration, were without grace. From this it followed that original and mortal sin deprived both the sinner and the infidel from all rights to lordship, jurisdiction and property.

Guglielmo Amidani of Cremona, Augustinian prior general (1326), was one of the theologians appointed by Pope John XXII to examine the Defensor Pacis of Marsilius of Padua, against which Guglielmo composed his own Refutatio Errorum. He used the arguments of Giles to prove the potestas directa of the spiritual power, i.e. that there is no temporal authority without spiritual power. As Katherine Walsh points out, it is significant that such an anti-Thomist and anti-Aristotelian doctrine could receive a favourable reception at the papal court so soon after the canonisation of St Thomas in $1323 .{ }^{18}$ Guglielmo was also present at the papal court at the time of John XXII's successor, Benedict XII, who was a friend of Grandisson, FitzRalph's patron. Thus he moved in similar circles to FitzRalph, and the Irishman may have derived the doctrine directly from him.

FitzRalph's Proposicio of 5 July 1350 stated his belief that God's grace was the foundation of valid lordship and the exercise of authority and jurisdiction; the corollary being that those who abused such rights and principles deserved to be deprived of them. His target here, just as later, was the Franciscan order. ${ }^{19}$ According to Firzralph, the Franciscans falsely claimed to live a life which was evangelica atque perfecta. He argued that they had transferred civil ownership of their property to the pope, thus giving themselves greater security, rather than using their property for the poor. Thus, they had sinned and abused their position and should be stripped of the privileges which the popes had mistakenly conferred on them.

In De Pauperie Salvatoris FitzRalph argues that positive laws were made necessary because of $\sin$, i.e. in order to repress evil. Indeed, in an ideal society the function of civil lordship would be superfluous. Before the Fall all temporal possessions would have been in common; private property had been introduced into the world only as a result of sin. In Book IV he argued that a man in the state of mortal sin lost his lordship over temporal goods. Yet FitzRalph never suggested that the Church or the civil authorities should confiscate anyone's goods. Wyclif would pursue this notion further, suggesting, like the Donatists of old, that a sinful priest could not validly carry out the

I8 See Walsh, A fourteenth-century scholar and primate, p. 383. I9 See J. Coleman, 'FitzRalph's Antimendicant proposicio (1350) and the Politics of the Papal Court at Avignon' in The Journal of Ecclesiastical History, 35 (1984), pp 376-90. 
functions of his office. The Augustinian friar Geoffrey Hardeby made this precise point against FitzRalph.

FitzRalph, it seems, never considered the practical implications of his doctrine outside of the context of the mendicant controversy. He did, however, argue that grace alone entitled a person to lordship over temporal things. As one historian has put it, the consequences of FitzRalph's theory were that since the title to exercise office and authority, as well as the enjoyment of property, was to be a subjective one, i.e. being in a state of grace, no-one, be he prelate, king, judge or merchant, could exercise functions implicit in his office or profession by virtue of election, appointment or consecration, or by virtue of inheritance, purchase, licence or charter.

It was a doctrine which was able to unmake popes, to trample episcopacy underfoot, to mutilate monasticism - the rights of sons to inherit, or labourers to their wage could be subjected to the same criteria - a further conclusion, which FitzRalph was careful to avoid but which was deduced from his dialogue both by a mendicant opponent and by Wyclif and the Lollards, concerned the effectiveness of the sacraments when administered by a sinful priest: no-one could be sure that they were not in a state of original sin for want of effective baptism, no woman could be sure that she was lawfully married; there could be no assurance of legitimacy, none that the sacrament of the altar was effectively performed; orders would be in doubt, absolution a conjecture, and extreme unction a gamble. ${ }^{20}$

It took Wyclif, Hus and Jerome of Prague, as well as the commission appointed by the Council Fathers at the Council of Constance (I4I4-17), who examined these views, to reach a precise formulation of the dangers implicit in FitzRalph's doctrines.

John Wyclif is a crucial figure in the development of this dispute in FitzRalph's wake. ${ }^{21} \mathrm{He}$ was born in Yorkshire around 1330 and educated at Oxford, becoming a doctor of divinity in 1372. In 1374, King Edward III appointed him rector of Lutterworth, and later made him part of a deputation to meet at Brussels with a papal deputation. About this time Wyclif began to argue for 'dominion founded on grace'. By 'dominion' he meant both the right to exercise authority in church or state and the right to own property. He maintained that these rights were given to men directly from God, and that they

20 R. R. Betts, 'Richard FitzRalph, Archbishop of Armagh, and the Doctrine of Dominion' in H. A. Cronne, T. W. Moody and D. B. Quinn (eds), Essays in British and Irish History in Honour of James Eadie Todd (London, 1949), pp 46-60; pp 50-51. Cited in Walsh, A fourteenth-century scholar and primate, p. 405. 2I Wyclif's indebtedness to FitzRalph was already recognized by R. Lane Poole in his 1890 edition of Wyclif's De dominio divino [Wyclif Society Publications, no. 14] (London 1890), to which he appended the first four books of FitzRalph's De pauperie salvatoris. On the relationship between FitzRalph's thought and that of Wyclif, see J.A. Robson, Wyclif and the Oxford Schools [Cambridge Studies in Medieval Life and Thought, New Series, vol. vIII] (Cambridge, 1966). See chapter three, 'Richard FitzRalph and the Conservative Tradition', pp 70-96. 
were not given or continued apart from sanctifying grace. Thus, a man in a state of mortal sin could not lawfully function as an official of Church or state, nor could he lawfully own property. He argued that the Church had fallen into sin and that it ought therefore to give up all its property, and that the clergy should live in complete poverty. This disendowment was to be carried out by the king. ${ }^{22}$ From 1376 to 1378 Wyclif was a clerical advisor to John of Gaunt, who effectively governed England until his nephew, Richard II, came of age in 1381. It is not clear what influence either man had on the other, but it is conjectured that John of Gaunt, who had his own reasons for opposing the wealth and power of the clergy, may have used a naive Wyclif as his tool. In 1377 , king and parliament solicited his judgement on whether it was lawful to withhold traditional payments from Rome. He replied that it was. Pope Gregory XI issued five bulls against him, but without effect. Wyclif's last political act was performed in 1378 , when he argued that criminals who had taken sanctuary in churches might lawfully be arrested. ${ }^{23}$

From retirement in Lutterworth Wyclif published a series of attacks on corruption in the Church. In I38I came the Peasants' Revolt. It is unlikely that Wyclif's teachings, which circulated chiefly among the learned, had any role in instigating the revolt, but the fact that many peasants set out to put to death all landlords, lay and clerical alike, made Wyclif's 'dominion founded on grace' look dangerous. Hence his intellectual tendency was bloodily suppressed along with the Revolt itself. In 1382 , all of his writings were banned. In that year Wyclif suffered a stroke, and on 3I December 1384 a second stroke killed him. After his death, his opponents had him condemned for heresy, and in 1428 his body was removed from consecrated ground.

Wyclif's view of dominion and grace depended on FitzRalph's theory according to which the original lordship was independent of natural and civil circumstances. It is a particular application of Wyclif's general views on election and damnation. The three main theses of the first book of his De civili dominio (1375-6) were

I. A man in sin has no right to dominion;

2. A man who is in a state of grace possesses all the goods of the world;

3. As a consequence, there can be no dominion without grace as its formal cause.

Wyclif defines dominion as the right to exercise authority and, indirectly, to hold property. A man in the state of grace is lord of the visible universe, which he shares with all other men in the state of grace. Since private property is the result of sin, all goods should be held in common, as was the case, he argued, before the Fall. In his prelapsarian state Adam enjoyed original lordship or the

22 See S.E. Lahey, 'Wyclif on Rights' in Journal of the History of Ideas 58 (1997), pp I-20. See also M. Wilks, 'Predestination, Property and Power: Wyclif's Theory of Domination and Grace' in Studies in Church History, 2 (1965), pp 220-36. 23 On Wyclif's life and writings, see Dictionnaire de théologie catholique, vol. XV, pp 3585-6r4; R. Sharpe, A Handlist of Latin Writers of Great Britain and Ireland before 1540 (Brepols, 1997), pp 347-54. 
lordship of an uncorrupted nature. Gospel lordship was a partial restoration of this original lordship. Civil lordship differed from both original and gospel lordship in being coercive and in making use of private property. ${ }^{24}$ Wyclif further argued that the best form of government was monarchy. Kings had to be obeyed and taxes paid to them, even if they became tyrants, since they were God's vicars whom He alone could depose. Thus it was secular lordship only that was justified in the world. Wyclif's doctrine of grace-founded dominium required the king to be a moral exemplar, that he wage only just war, that he keep laws and taxes to a minimum and that he protect a possession-less Church. However, Wyclif's political theory was anti-authoritarian, inasmuch as no civil dominium, including both property ownership and civil jurisdiction, could be granted in perpetuity. Again, Wyclif was anti-feudal in that he held that biological, hereditary succession did not confer dominium.

These problems achieved temporary closure in the Middle Ages with the declarations of the Council of Constance which condemned Wyclif's teaching on dominium. Hus was burnt as a heretic and Wyclif's bones taken out of hallowed ground. FitzRalph, however, escaped censure. By the sixteenth century, the idea that grace might entitle one to rule over those who were not in a state of grace began to have a new use, namely that of justifying the occupation of the territories of the New World and the deposition of native rulers. The notion in Roman law of res nullius could be appealed to in order to justify the acquisition, through occupation, of uninhabited territories, but it was difficult to apply in countries inhabited by people organised into a political society. One wonders what the natives made of the English general Sir Humphrey Gilbert, who, when he took possession of the harbour of St John in Newfoundland in 1583, promulgated three laws making the Church of England the official church, setting out a crime of high treason for anything attempted against the possession of these territories and a second for slander against Elizabeth I.

What in effect was at stake was the right to territorial sovereignty of the native peoples against the counterclaims to world government of the European states. The latter derived from Roman claims to possession over all the earth. Long after the fall of the empire, as European travellers 'discovered' new territories and annexed them, they clung to the Roman idea that they were bringing these new lands into the 'known' world. Thus, when Colombus discovered the New World, he believed that he had brought the populations of the Americas into the light and the world. For him, the native populations were not entitled to the same rights enjoyed by Europeans.

The claims of the Spanish overseas empire were based on two interlocking claims to universal authority: the first derived from the pope in the Bulls of

24 See A. S. McGrade, J. Kilcullen and M. Kemshall (eds), The Cambridge Translations of Medieval Philosophical Texts, Vol. II: Ethics and Political Philosophy (Cambridge, 2001), particularly chapter 17 'John Wyclif on Lordship' (Selections), pp $587-654$, p. 589. 
Donation of 1493 , which granted sovereignty of everything in the Atlantic and which was based on the universalism of the Christian religion; ${ }^{25}$ the second claim was that the Holy Roman Emperor had a de iure right to universal rule. ${ }^{26}$ It followed that, though he might not actually rule over all of the peoples 'discovered and yet to be discovered', he had the right to. The first rejection of the imperial claim came with the writings of the Spanish theologian, Francisco de Vitoria (c. I485-I546)

De Vitoria was one of the most influential political theorists in sixteenthcentury Catholic Europe. He was a theologian by profession and someone for whom theology, as the 'queen of the sciences,' covered all domains, including jurisprudence. He spent most of his life as a university professor at Paris and Salamanca. While at Paris, he attended lectures by the Flemish theologian Peter Crockaert, who was the first there to substitute the text of the Summa theologiae for the Sentences of Peter Lombard. De Vitoria would later do the same at Salamanca. It was there that he formed two generations of Spanish theologians and jurists including Luis de Molina (I535-1600) and Francisco Suárez (1548-16I7). He was instrumental in the renewal of scholastic thought that earned the school of Salamanca its reputation and fuelled the Second Scholasticism.

The most pressing issue in contemporary politics during de Vitoria's time was the legitimisation of the Spanish conquest of the New World. This debate began when King Ferdinand appointed a commission of theologians and lawyers to discuss the matter in 1513 . The problem became acute, however, with the discovery and conquest of Mexico in 1520-22 and Peru in I531-32. The invasion and virtual destruction of great empires raised questions. In his lectures on the Summa in 1534-35, de Vitoria argued that coercion could only be used when crimes that went against nature, such as human sacrifice and cannibalism, were committed. Intervention was justified only because such acts were harmful to our neighbours and because the 'defense of our neighbours is the rightful concern of each of us' ${ }^{27}$

De Vitoria repeated the main points of Aquinas's teaching on natural law. However, the former applied the notion of the knowability of first principles of the moral order to all rational beings in order to argue for a basis for international agreement, the famous ius gentium. This law of nations was a term which served to indicate those laws which embodied a set of precepts enacted by the power of 'the whole world, which is in a sense a commonwealth' irrespective of local legislative concerns, beliefs, customs of individual communities, or indeed their place in time.

25 See A. Pagden, 'Shadows on an unquiet sleep: America and the competing discourses of European Universalism', paper delivered to 1997 CUNY Renaissance Studies Conference entitled 'Early Modern Trans-Atlantic Encounters: England, Spain and the Americas' available on-line at http:// web.gc.cuny.edu/dept/renai/conf/Papers/Keynote/Pagden.htm. 26 Francisco de Vitoria, Relectio de Indiis (On the American Indians), q. 2, a. 2. See Fransisco de Vitoria, Political Writings, edited by A. Pagden and J. Lawrance, (Cambridge, 1991), pp xxiv, 260-6r. 27 Francisco de Vitoria, Political Writings, p. xxiii. 
For de Vitoria (though not explicitly for Aquinas) international law was an essential part of positive law, but since it was meant to apply to all peoples it had to be closer to the precepts of natural law. The contentious issues of de Vitoria's time were the nature of civil power and kingship, the power of the papacy and the question of the legitimacy of the European expansion into the Americas. With regard to the latter, de Vitoria argued that non-Europeans had rights and protection under the ius gentium and were subject to no other positive law than their own. It was de Vitoria's observations on the implications of this and his questioning of the legitimacy of the Spanish invasion of America which led to his maintaining that there are principles of natural justice which are applicable to all human beings.

De Vitoria sought to reinforce Aquinas's arguments that all rights (iura) were natural and were (ultimately) the consequences of God's eternal law and not a matter of God's grace, or divine (revealed) law. Aquinas had written

Here we must consider that dominion and government are matters of human law, while the distinction between believers and non-believers is a matter of divine law. Now the divine law which is based on grace does not abolish human law which is based on reason. Therefore, the mere fact of a difference between believers and unbelievers does not abolish dominion or government by unbelievers over believers. ${ }^{28}$

And again

The order of justice is not abolished but rather confirmed by faith . . The order of justice requires that inferiors obey their superiors, for otherwise stability could not be maintained in human affairs. Therefore, the Christian faith does not exempt the faithful from obeying secular rulers. ${ }^{29}$

He held that unbelievers should in no way be forced to believe, for faith, he said, was a matter of the will. ${ }^{30}$ Further he insisted that 'all men are equal by nature' and 'all should have some part in government'. ${ }^{31}$ The contrasting claim, as we have seen, was made by Wycliff and Hus and, in de Vitoria's own time, by the Lutherans, to the effect that rights, and hence the authority of secular rulers, were dependent on God's grace. Thus, if a ruler was a heretic or a sinner his laws could not be binding in conscience: only a righteous ruler could be a just legislator. An unrighteous ruler could be deposed and such 'unrighteous' included unbelievers.

What is interesting is that de Vitoria correctly traces the doctrine to its source in Richard FitzRalph. FitzRalph, as we have seen, argued that dominium or lordship of the world belonged properly only to God and that he admitted man to a share of his dominium out of grace. Hence only those who enjoy his

28 S.Th., II IIae, q. Io, a. 10. 29 S.Th., Ila Ilae, q. IO4, a. 6. 30 S.Th., Ila Ilae, q. ro, a. 6. 31 S.Th., Ila Ilae, q. 104, a. 5 ; lallae q. IO5, a. I. 
grace share his dominium. De Vitoria refers specifically to FitzRalph in a number of places throughout his works. In On the Civil Power (I528), q. I, a. 6, he asks if non-Christians have legitimate sovereigns. He states

Richard FitzRalph, archbishop of Armagh, a man of otherwise blameless character and intelligence, certainly argues in his De pauperitate Saluatoris that not merely unbelief but any mortal sin impedes any kind of power or dominion (dominium) or jurisdiction, either public or private, in the mistaken belief that the true title and foundation of all power is grace. Nevertheless, the authorities and arguments which he adduces to try to prove this assertion are so weak and unworthy of consideration for the solution of this problem that I shall not waste my time over them. To this one may therefore answer that there can be no doubt at all that nonbelievers have legitimate rulers and masters. ${ }^{32}$

Now Roman law made a distinction between possessio (the control of a thing irrespective of whether a possessor has a right to it or not) and dominium (the right to a thing, irrespective of whether the owner has control over it or not). De Vitoria fought against the notion of dominium through grace (it was condemned later at the Council of Trent) because it could be used to argue that the peoples of the 'New World' merely had control over their lands and not a right to them because they were unbelievers. Thus, Christians would be entitled to take the lands, wealth and property from the native Americans because Christians can and should exercise dominium over all unbelievers and over the whole world. This, of course, would render natural rights, or those which belong to human beings precisely because they are human, null and void. It was natural law theory that enabled de Vitoria to argue against this position.

In his first relectio, ${ }^{33}$ On the American Indians (given in 1539, published in 1557), de Vitoria pointed out that

This whole dispute and relectio has risen again because of these barbarians in the New World, commonly called Indians, who came under the power of the Spaniards some forty years ago, having been previously unknown to our world. . . My present discussion of these people will be divided into three parts: first, by what right were the barbarians subjected to Spanish rule? Second, what powers have the Spanish monarchy over the Indians in temporal and civil matters? And third, what powers has either the monarchy or the Church with regard to the Indians in spiritual and religious matters?34

32 Francisco de Vitoria, De potestate civili (On the Civil Power) q. I, a. 6. See Political Writings op.cit., p. I8. 33 De Vitoria gave lectures on Aquinas's Summa theologiae and the Sentences of Peter Lombard but these were continuous commentaries upon set texts, as was the tradition. The relectiones, or 'rereading', allowed the teacher to focus upon particular problems arising from the text or to deal with matters of contemporary interest. 34 Francisco de Vitoria, Relectio De Indiis, prooemium (Political Writings, p. 233). 
He questions whether the treatment of the native Americans by the Spaniards is in keeping with justice and unwittingly echoes the concerns of FitzRalph some two centuries before:

But when we hear subsequently of bloody massacres and of innocent individuals pillaged of their possessions and dominions, there are grounds for doubting the justice of what has been done. ${ }^{35}$

He asks 'whether these barbarians, before the arrival of the Spaniards, had true dominion, public and private' (q. I, a. I) (i.e. did they have rights of ownership?). ${ }^{36}$ And he raises the question, 'whether there existed among them any men who were true princes and masters of the others' ${ }^{37}$ He says

If the barbarians were not true masters before the arrival of the Spaniards, it can only have been on four possible grounds . . . These four grounds are that they were either sinners, unbelievers, madmen or irrational. ${ }^{38}$

He then proceeds to argue that 'mortal sin is no impediment to the civil right of ownership nor to true dominion' 39 and 'it is no impediment for a man to be a true master, that he is an unbeliever. ${ }^{40} \mathrm{He}$ adds that 'the barbarians are not impeded from being true masters, publicly or privately, either by mortal sin or by the particular fault of unbelief' ${ }^{4}{ }^{\mathrm{I}}$ He goes on to say

The conclusion of all that has been said is that the barbarians undoubtedly possessed as true dominion, both public and private, as any Christians. That is to say, they could not be robbed of their property, either as private citizens or as princes, on the grounds that they were not true masters. It would be harsh to deny to them, who have never done us any wrong, the rights we concede to Saracens and Jews . . . . ${ }^{2}$

In I5IO, the Scottish Dominican John Mair had suggested that the American Indians might be slaves by nature. The origin of such a doctrine was attributed to Aristotle in the Politics (I and III), who suggested that there might be groups of barbarians who were not fully capable of understanding and so of directing their actions in a proper manner. As such they could not have exercised dominium before the conquests, since they would not have been able to live in civil society. De Vitoria rejected these claims, on the grounds that the Indians did in fact have an order in their affairs. They lived in cities, had a

35 Francisco de Vitoria, Relectio De Indiis, prooemium (Political Writings, p. 238). 36 Francisco de Vitoria, Relectio De Indiis, q. I, a. I (Political Writings, p. 239). 37 Francisco de Vitoria, Relectio De Indiis, q. I, a. I (Political Writings, p. 239). 38 Francisco de Vitoria, Relectio De Indiis, q. I, a. I (Political Writings, p. 240). 39 Francisco de Vitoria, Relectio De Indiis, q. I, a. 2 (Political Writings, p. 24I). 40 Francisco de Vitoria, Relectio De Indiis, q. I, a. 3 (Political Writings, p. 244). 4I Francisco de Vitoria, Relectio De Indiis, q. I, a. 3 (Political Writings, p. 246). 42 Francisco de Vitoria, Relectio De Indiis, q. I, concl. (Political Writings, p. 251). 
recognised form of marriage, magistrates, overlords, laws, industries, and commerce, 'all of which require the use of reason'. ${ }^{43}$

De Vitoria then went on to consider various reasons that have been put forward to excuse the Spaniards for taking possession of Indian land and property. In question 2 he rules out a series of unjust titles that, it was claimed, might empower Christians to take possession of the property of the barbarians.

The first unjust title (q. 2, a. I) which de Vitoria examines is that 'our most serene Emperor (Charles V) might be master of the whole world'. This is rejected as without foundation on the grounds that the emperor is not the master of the whole world. He is not master of the world by any law, natural, divine or human. ${ }^{44}$ The second unjust title examined (q. 2, a. 2 ) is that the just possession of these countries is on behalf of the supreme pontiff. 'Those who defend this title - and it has energetic supporters - assert that the pope is monarch of the whole world, even in temporals, and consequently that he was empowered to constitute the kings of Spain as kings and lords of those lands.' De Vitoria rejects this argument, asserting that the Pope does not possess jurisdiction over other nations except in spiritual matters. Following Aquinas, ${ }^{45} \mathrm{de}$ Vitoria acknowledged the right of the Pope to intervene in secular matters when these touch upon spiritual concerns, such as the waging of war, peace treaties and the salvation of souls. This, however, is far from asserting the direct subjugation of temporal powers to the spiritual, or that Pope Alexander VI had the authority to grant possession of these new lands in the Bulls of Donation. Since the pope's right to intervene in secular matters was limited to spiritual concerns, he lacked power both spiritual and temporal over non-believers and could not confiscate their lands as a punishment for sins. The third unjust title (q. 2, a. 3) concerns the notion that the possession of these countries is by right of discovery. The argument is that 'the Spaniards, who were the first to discover and occupy these countries, must by right possess them, just as if they had discovered a hitherto uninhabited island'. But this is a false claim because, as de Vitoria has already shown, the Indians already possessed 'true public and private dominion'. ${ }^{6}$ These lands were already in their ownership. The fourth unjust title (q. 2, a. 4) rests on the claim that they refuse to accept the faith of Christ. De Vitoria rejects this argument as inadequate. 'It is not sufficiently clear to me that the Christian faith has up to now been announced and set before the barbarians in such a way as to

\footnotetext{
43 Francisco de Vitoria, Relectio De Indiis, q. I, a. 6 (Political Writings, p. xxv; 250). 44 Francisco de Vitoria, Relectio De Indiis, q. 2, a. I (Political Writings, p. 253). 45 See, S. Th. IIa IIae, q. 6o, a. 6: The secular power is subject to the spiritual power as the body is subject to the soul. Therefore the power to judge is not usurped if a spiritual authority enters into temporal affairs in matters in which the secular power is subject to it or which have been given to it by the secular power. Again. Thomas writes in his Commentary on the Sentences, II, dist. 44, q. 2: Both the spiritual and the secular powers are derived from the power of God. Therefore, the secular power is only under the spiritual power to the extent intended by God, namely, in the matters that relate to the salvation of souls. Therefore, in these matters the spiritual power is to be obeyed rather than the temporal. In those matters that pertain to the good of civil society the secular power is to be obeyed rather than the spiritual .... 46 Francisco de Vitoria, Relectio De Indiis, q. 2, a. 3 (Political Writings, p. 264).
} 
oblige them to believe it. ... I have not heard of any miracles or signs, nor of any exemplary saintliness of life sufficient to convert them. On the contrary, I hear only of provocations, savage crimes, and multitudes of unholy acts'. ${ }^{47}$

Thus, it would seem that de Vitoria echoes the concerns of FitzRalph, even if he does not agree with the Irishman's principles. In Question 3 de Vitoria turns to possibly just titles by which the Indians passed under the rule of the Spaniards. In doing so, he begins the process of working out what we might call international rights, covering freedom of travel, trade and religion. It has been argued that de Vitoria was here establishing a law of nations, which would become the international law, not just of Christian states, but of the whole world.

Claims to world empire were also dismissed by de Vitoria's pupil Domingo de Soto, who argued that civil power could only be transferred by society acting as a body. For a universal empire to be possible, it would be necessary to call a general assembly of the whole world. This was hardly feasible. In his De iustitia et iure of 1556 de Soto made a rather imaginative use of the Aristotelian principle that something can only grow to the extent that is set for it by nature. Thus, human government also has its natural limits: one state cannot rule the whole world. A universal or global rule would be neither natural nor legitimate. Given that all peoples are different from one another, each must be governed according to its own needs, local customs and local rulers. He further noted that all civil power depended on voluntary submission to a ruler who was 'elected' by the people. Civil power derived its legitimacy from custom. Thus, empires rise and fall; the power of one country cannot and should not extend to the whole world. $4^{8}$

Despite the defence of the rights of non-Christian peoples to individual sovereignty by these Thomists, as we know the history of the New World turned out to be rather different. European nations used a variety of tactics in order to lay claims to these 'new' lands: symbolic acts such as the planting of flags; discovery understood as conferring inchoate title, to be completed by occupation within a reasonable time; treaties with the indigenous populations, whereby their lands were purchased from them; treating these lands as res nullius in cases where they were not occupied already by other Europeans; falling back on just war theory when native populations resisted. In general, the Spanish and Portuguese appealed to papal documents and treaties to enforce their claims and justified their occupation as serving the purposes of conversion. For the English of this period, however

The law of Nature and nations had acquired in England a new meaning. A new interpretation was placed upon it in accordance with Protestant thought and English interests. The sovereignty of the native races was ignored, a decided, though unconscious tribute to the genius of Wycliffe.

47 Francisco de Vitoria, Relectio De Indiis, q. 2, concl. (Political Writings, p. 27I). 48 The opposition to the idea of one world empire is also found in Augustine, De civitate Dei, IV, is. 


\section{ARCHIVIUM HIBERNICUM}

Discovery followed by settlement, thus leading to occupation, or, more rarely, the simple right of conquest, was relied on as a title. ${ }^{49}$

FitzRalph would probably have disapproved this development of his original notion of dominion. A principle which he intended to bring some measure of justice into law in his own diocese was later used to support laws without principle on the international stage.

49 J. Holland Rose, A. P. Newton, and E. A. Benians (eds), The Cambridge History of the British Empire, Vol. I, Chapter six, 'International Law and the Outer World, I450-I648', p. 193.

258 